\title{
"Put on your own mask before helping others": The capacity of food hubs to build equitable food access
}

\author{
Lesli Hoey ${ }^{* *}$ and Lilly Fink Shapiro ${ }^{b}$ \\ University of Michigan \\ Noel Bielaczyc ${ }^{c}$ \\ Michigan State University
}

Submitted April 4, 2018 / Revised July 1, 2018 / Accepted August 3, 2018 / Published online

November 18, 2018

Citation: Hoey, L., Fink Shapiro, L., \& Bielaczyc, N. (2018). "Put on your own mask before helping others": The capacity of food hubs to build equitable food access. Journal of A griculture, Food Systems, and C ommunity D evelopment, 8(3), 41-60. https:/ / doi.org/ 10.5304/ jafscd.2018.083.012

Copyright ( 2018 by the Authors. Published by the Lyson Center for Civic Agriculture and Food Systems. Open access under CC BY license.

\begin{abstract}
In a bifurcated U.S. food market, where one market is largely controlled by national brands and global corporations alongside an expanding alternate market of hyper-local direct sales, midscale producers and processors are struggling to persist. One emerging strategy for rebuilding this middle of the food system - food hubs- has gained attention as a model that could rebuild local food economies

\footnotetext{
a * C orresponding author: Lesli Hoey, Urban and Regional Planning Program, University of Michigan; 2000 Bonisteel Blvd., Art and Architecture Building, Ann Arbor, MI 48109 USA; +1-734-936-0212; lhoey@ umich.edu

b Lilly Fink Shapiro, Sustainable Food Systems Initiative, School of Environment and Sustainability, University of Michigan, 440 Church St., Ann Arbor, MI 48109-1041 USA; +1-513-368-2311; finkshap@ umich.edu

c Noel Bielaczyc, Center for Regional Food Systems, Michigan State University; 480 Wilson Road, Natural Resources Building; East Lansing, MI, 48824 USA; +1-517-432-0093; bielacz1@anr.msu.edu
}

and equitable food access. Through an examination of Michigan food hubs, we ask about the extent to which and under what conditions food hubs can operationalize dual economic and social goals. We found many innovations and efforts to address food access in low-income communities- especially among food hubs that were nonprofits, had been operating for less time, and were more

\section{Funding Disclosure}

The evaluation and the operation of the Network were funded by the W.K. Kellogg Foundation and the Kresge Foundation, but neither foundation was involved in conceiving of this study or in writing the article.

\footnotetext{
Author N ote

The participant observation noted in the methods refers to the role that two of the authors played as external evaluators of the Michigan Food Hub Learning and Innovation Network, a network that the third author co-facilitates. However, the majority of the data collection for this study was completed outside the bounds of the Network evaluation activities. Portions of these findings were presented at the 2017 conference of the Association of Collegiate Schools of Planning.
} 
dependent on external revenue- but their impact tended to be small-scale and uncertain. Most food hubs want to do more, but our study suggests they may not be able to until they can figuratively "put on their own mask before helping others." That is, food hubs may be one means of increasing affordable, healthy food access in certain scenarios, but equitable food access may be an unrealistic and unsustainable goal unless they can ensure their own financial stability. Among other options for satisfying the requirements for equitable food access, financial survival, and returns to the farm gate, our findings suggest that food hubs attempting to reduce food access inequities may need to be subsidized as a public good, unless and until the public sector commits to a more comprehensive strategy to address food system failures.

\section{Keywords}

Food Hubs, Food Access, Agriculture of the Middle, Food System Planning, Michigan

\section{Introduction}

The U.S. food market has increasingly come to resemble two systems: the mainstream market controlled by national brands and globally focused corporations, and an expanding alternate market of hyper-local direct sales. This bifurcation is tied to a gradual loss of structural diversity in the food system, particularly in midscale regional production and processing, which is seen as key to scaling up more sustainable, economically viable, and socially equitable food businesses (Stahlbrand, 2017; Stevenson, Clancy, King, Lev, O strom, \& Smith, 2011). O ne emerging strategy for rebuilding this middle of the food system - food hubs- aims to connect small and midsized farms to schools, hospitals, restaurants, retailers, and other buyers through aggregation and distribution infrastructure at the regional scale.

As food hub models attract public and private investment, diverse stakeholders are hopeful that they can support thriving local food economies while also increasing equitable food access. The U.S. D epartment of Agriculture (USD A), for instance, states that "food hubs are providing wider access to institutional and retail markets for small to mid-sized producers, and increasing access to fresh healthy food for consumers, including underserved areas and food deserts" (Barham, 2010, para. 3). The 2016 National Food Hub Survey report (Hardy, Hamm, Pirog, Fisk, Farbman, \& Fischer, 2016) also states that food hubs are "a part of the solution of the complex problem of food and nutritional insecurity" (p. 7), with similar claims made by academics (e.g., Glaza, 2013; Rose 2017), foundations (e.g., Surdna Foundation, 2014; Vitalist Health Foundation, n.d.), and nonprofits (e.g., Cooper, 2018; Healthy Food Access Portal, n.d.). While research is mounting to show how food hubs are creating jobs, offering fair prices to farmers, and sparking wider economic development (Colasanti, Hardy, Farbman, Pirog, Fisk, \& Hamm, 2018; Jablonkski et al., 2016), evidence about food hubs' contributions to affordable, local food access is both understudied and inconclusive (Berti \& Mulligan, 2016).

Through an in-depth examination of Michigan food hubs, this paper seeks to untangle these expectations from practice. We ask about the extent to which and under what conditions food hubs can successfully operationalize dual social and economic goals.

Structural Changes in the U.S. F ood System and the Rise of $\mathrm{F}$ ood $\mathrm{H}$ ubs

The erosion of regional food systems and the continued loss of midsized farms, ${ }^{1}$ especially since the 1980s, has been widely documented (Feenstra \& Hardesty, 2016; Kirschenmann, Stevenson, Buttel, Lyson, \& D uffy, 2008; MacD onald \& Hoppe, 2018). Technological innovation in production methods and vertical integration of the food industry has played a major role in shifting production to larger farms, but many other complex processes are implicated as well, including agricultural policy and trade, farmer debt, commodity price fluctuations, shifting demographics, globalized economies, and more (MacD onald \& Hoppe, 2018; Woods, 2014). In the case of livestock industries, rapid vertical

\footnotetext{
${ }^{1}$ By midsized and midscale producers, we mean farms with gross sales from US $\$ 150,000$ to US $\$ 500,000$, which draws on definitions used by Kirschenmann et al., 2008, Feenstra and Hardesty, 2016, and the USD A Farm Typology (USD A, 2015).
} 
integration of production, processing, and marketing was enabled by the adaptation of more efficient production models, specialization by producers, geographic concentration, and contract farming (Abdalla, 2002; USD A, 2010). Likewise, fruit and vegetable supply chains have experienced significant concentration through intensified production and grower-processor integration (MacD onald, Hoppe, \& Newton, 2018). At the same time, ownership of the grocery retail sector (and its distribution infrastructure) have become highly consolidated, applying downward price pressure on growers, packers, and processors (Hendrickson, Heffernan, Howard, \& Heffernan, 2001).

Today, midscale agricultural producers are both too large to operate in direct markets and too small to compete in the commodity market (Feenstra \& Hardesty, 2016; Kirschenmann et al., 2008). Recent efforts to renew "agriculture of the middle" have recognized the key role that "infrastructure of the middle" plays in linking midsized farms and scale-appropriate regional markets like schools, universities, and hospitals (Hardesty et al., 2014; Stahlbrand, 2017). Although they are in decline, fragmented, and unevenly distributed, a modest portion of this midscale infrastructure remains intact; family-owned distributors, produce houses, meat plants, and processing facilities can still be found scattered across rural and urban communities (Stevenson et al., 2011; USD A, 2010). At the same time, other changes in the food system have created new business opportunities for small and midsized producers and their business partners. Consumer demand has been shifting to include other values beyond price, such as locality and transparency, in reaction to health, environmental, and social concerns associated with a globalized food system (Zepeda \& D eal, 2009). In addition, web-based food enterprise has disrupted conventional retail systems and created opportunities for innovative food businesses and direct marketing (Berti \& Mulligan, 2016).

Food hubs have the potential to thread together these new business opportunities, increased demand for local food, and fragmented remains of midscale infrastructure. D efined as operations that focus on the aggregation, distribution, and/ or processing of "source-identified food products" that are primarily local and regional (Fischer, Pirog, \& Hamm, 2015, p. 93), food hubs have expanded quickly across the U.S. in the last 10 years, more than doubling since 2009 to nearly 400 today (Colasanti, Hardy, Farbman, Pirog, Fisk, \& Hamm, 2018; USD A, 2016).

Theoretical F ramework and the State of the E vidence To help explain why food hubs may or may not be able to affect affordable food access, we draw on the theoretical framework that Stroink and Nelson (2013) developed, based on social-ecological and complex adaptive systems theories. Structured around the idea that complex systems, like food systems, move through an adaptive cycle, they describe how the current, industrial system is facing a "rigidity trap" where the system is highly "structured and efficient... homogenous, resistant to change and rigid," but also "more vulnerable to major disturbances" (p. 632). In reaction, food hubs (alongside many other food movement initiatives) are engaging in experiments to address multiple issues created by the dominant food system. Stroink and Nelson (2013) argue, however, that this start-up stage is beset by "numerous false starts and failed experiments" and that most emerging food hubs, regardless of their legal model, will face a "poverty trap" (p. 628). Unable to secure sufficient capacity and capital to grow, newly established food hubs will likely "spread themselves too thin" (p. 628) with insufficient resources to tackle all their goals, resulting in a limited impact on food access and other food systems problems (Stroink \& Nelson, 2013). The goal is for food hubs to make it out of this poverty trap so they can begin to grow, increase their productivity and efficiency, leverage resources, and attempt to remove structural barriers to growth, such as inappropriate policies.

Stroink and Nelson (2013) found that the five food hubs they studied in Canada were able to "carve out niches of capital" (p. 632) while also contributing to equitable food access and new markets for local farmers. They also argue, however, that these efforts were still "limited and kept largely isolated" because food policies - as well as resources, training, research, and infrastructureare often oriented toward an industrial food system 
that undermines small and midsized producers and processors (Stroink \& Nelson, 2013). O ther scholars have shown that food hubs can fully incorporate their social missions once they scale up sufficiently to become financially viable (Cleveland, Müller, Tranovich, Mazaroli, \& Hinson, 2014; Feldstein \& Barham, 2017; Fischer et al., 2015), while one study found that food hubs can lose their commitment to low-income food access as they scale up (Franklin, Newton, \& McEntee, 2011).

Case studies have also shown how both nonprofit and for-profit food hubs have placed lowincome food access at the forefront of their operations, but these studies also tend to acknowledge that the hubs are either heavily dependent on grants or still in the start-up phase, where they face considerable financial challenges (Cohen \& Derryck, 2011; Cooper, 2018; Levkoe \& Wakefield, 2011). On the other hand, Hodgins and Fraser's (2018) research on the impacts of 43 alternative food businesses on access among low-income consumers shows how operational constraints and financial viability were key barriers, but they concluded that a more important impediment was that business leaders were unaware of inequitable food access or showed a "lack of concern about lowincome customers" (p. 154). However, these findings were blended across farmers markets, intermediaries (including food hubs), and social enterprises.

\section{Study Location}

Our study builds on this initial, but inconclusive, research base to examine more closely the mechanisms that may be supporting or limiting the efforts of food hubs to address equitable food access. We chose to focus on Michigan for several reasons. First, Michigan's unique geographic conditions (e.g., microclimates created by the $\mathrm{G}$ reat Lakes, fertile soil, ample water supply) have made agriculture one of Michigan's top industries (Michigan D epartment of Agriculture \& Rural D evelopment [MD ARD ], 2018), second only to California in agricultural diversity (Lovejoy, Buhler, $\&$ Hanson, 2010). Michigan is also illustrative of the bifurcating food market throughout the U.S. Direct sales through farmers markets and community supported agriculture operations (CSAs) became particularly pronounced after the 1980s global recession, as the state invested heavily in export-oriented, industrial agriculture, requiring small and midsized farms to become entrepreneurial in order to survive (D eLind \& Benitez, 1990; Veeck, Che, \& Veeck, 2006). At the same time, high rates of obesity, food insecurity, and limited access to fresh fruit and vegetables are apparent across urban and rural communities (Centers for D isease Control and Prevention [CDC], 2016; G undersen, D ewey, Crumbaugh, Kato, \& Engelhard, 2018). Concerns about uneven food access, in part, motivated hundreds of stakeholders to commit to the Michigan Good Food Charter in 2010, one of the first of its kind nationally (Colasanti et al., 2010).

Michigan is also home to one of the first technical assistance networks for food hubs in the U.S.: the Michigan Food Hub Learning and Innovation Network (MFHLIN). Launched in 2012, the MFHLIN leveraged state funding to establish a core group of food hubs "to help Michigan regional food and farm businesses succeed" (Michigan State University Center for Regional Food Systems [MSU CRFS], 2017, p. 1). Another stated goal is to "measurably increase healthy food access to low-income communities and vulnerable children in order to increase healthy outcomes" (MSU CRFS, 2017, p. 1). Prior to 2012, Michigan could claim two food hubs. In 2018, a dozen food hubs are operating, both small and large, serving anywhere from two to 800 institutional customers. In sum, this diversity of food hubs, the presence of a statewide food hub network focused on food access, and the broader context of a diverging agricultural economy made Michigan an ideal site for our study.

\section{Methods}

Given the dynamic nature of emerging food hubs, we used methods that would allow us to systematically compare food hubs and explore the issues that might influence their ability to engage in activities related to food access. This included a structured survey and semistructured interviews with individuals running food hubs in Michigan, an analysis of food hubs' mission statements, 
interviews with a broader group of stakeholders who work with food hubs, and participant observation of MFHLIN meetings. ${ }^{2}$

To identify food hubs for the study, we collaborated with conveners of the MFHLIN to locate operations in the state that self-identified as a food hub in late 2016. As we became aware of additional food hubs that emerged during the course of the study, we added two more, resulting in a total of 11 food hubs. Between August 2016 and October 2017, food hub managers, ${ }^{3}$ executive directors, and co-owners (hereafter referred to as "food hub managers") from these 11 food hubs completed a survey modeled after the 2015 National Food Hub Survey (Hardy et al., 2016). In addition to asking in the survey about each food hub's legal status, mission, business model, core function(s), and activities related to healthy food access, we also analyzed written mission statements located on each of the food hub's websites or reports.

We then completed interviews lasting one hour with 13 food hub managers from the 10 hubs that agreed to participate. Using a semistructured interview approach $(\mathrm{Qu} \&$ D umay, 2011) allowed us to clarify the answers provided in the survey and delve further into perceptions, strategies, and barriers related to addressing food insecurity. We also contextualized these perspectives by interviewing key informants who work with food hubs in a variety of ways (referred to throughout as "food hub partners"). Using snowball sampling (Atkinson \& Flint, 2001), we identified eight food hub partners, including three university-based and nonprofit-based food hub consultants who have been instrumental in launching or running the MFHLIN; three people who previously ran a food hub or are just beginning to engage in food aggregation (all of whom are involved in the MFHLIN and play other roles, including consulting with food hubs, leading a food justice nonprofit, and running a farm); one scholar doing research on food hubs in the Midwest; and one grant officer from a national foundation that funds Michigan food hubs.

One or all members of our study team also participated in five MFHLIN meetings held during our data-collection process. These meetings included two that convened members of the Food Hub Network and three joint meetings held with other Michigan-based networks focused on farmto-institution programs, incubator kitchens, and food policy councils. O ur unstructured observation of these meetings helped us identify relevant research questions early on and triangulate themes that emerged in our survey and interviews.

We used descriptive statistics to analyze the survey and thematic coding (Fereday \& MuirCochrane, 2006) to identify shared and contrasting priorities, strategies, and perspectives in the interview transcripts and mission statements. A summary of the survey results and interview themes by food hub, overall averages, and national comparisons based on the 2017 National Food Hub Survey (Colasanti et al., 2018) are displayed in Table 1. In Table 2, results compare groupings of food hubs based on three factors that the literature tends to identify as key to explaining food hub strategies and successes: their legal status, years in operation, and dependence on grants and other external reve nue. All themes and quotes- other than those that could compromise the anonymity of a food hubare identified in the findings using unique codes, including " $\mathrm{FH}$ " for food hubs and the assigned ID in Table 1 (e.g., FH1, FH2) and "P" for the food hub partners (e.g., P1, P2).

\section{Findings}

As the remainder of our findings expand upon, most food hubs in this study - but especially nonprofits, newer food hubs, and those more dependent on external funding - prioritize or carry out activities focused on food access in economically disadvantaged communities. Our findings also show that these efforts are limited by a number of challenges. Nonetheless, food hub managers and their partners are still hopeful that a number of pathways exist for supporting food hubs to simultaneously improve equitable food access, their own financial survival, and returns to the farm gate.

2 This study was approved by the Internal Review Board at the University of Michigan.

3 Three of the food hub managers (FH1, FH9, FH11) are also active farmers, offering a producer perspective. 
$\mathrm{G}$ eneral $\mathrm{F}$ ood $\mathrm{H}$ ub Characteristics

Compared to food hubs nationally (Colasanti et al., 2018), a smaller percentage of food hubs in this study consider themselves nonprofits ( $27 \%$ vs. $42 \%$ nationally) or for-profits ( $27 \%$ vs. $37 \%)$, with more operating with "mixed" legal models 4 ( $45 \%$ vs. $21 \%$ ) (See Table 1). Food hubs in our study have also been in operation for only 3 years on average, compared to the national average of 9 years (Colasanti et al., 2018), although this varied considerably based on the legal model, with mixed models in operation for 1.5 years, nonprofits for 2.2 years, and for-profits for 6.7 years. On average, the Michigan hubs rely on $40 \%$ of external revenue from grants, donations, or government funding, while $36 \%$ rely on no external funding, compared to $64 \%$ of hubs nationally (Colasanti et al., 2018). Nonprofits in our study rely most on external funding ( $70 \%$ on average), compared to $46 \%$ for hubs with mixed models and no external funding among for-profits. Hubs in operation for a year or less are also more dependent on external funding (53\% on average) compared to those that have been operating for three or more years (28\%). In addition to outpacing other hubs on food access activities (discussed further below), the hubs that are nonprofits (and sometimes mixed models), a year old or less, and either moderately or highly dependent on external funding are also most likely to source from female farmers, farmers of color, beginning producers or suppliers, and small or medium farmers, and are also more likely to sell to customers who are under 50 miles (80 kilometers) away (Table 2).

$\mathrm{V}$ iews, Intentions, and $\mathrm{A}$ ctions Related to Food A coess

All the food hub managers interviewed agreed that access to affordable, healthy food is a problem, either in their immediate vicinity or in surrounding communities. They used words like "food apartheid" (FH 4) and "food swamps" (FH 11) to describe places that are flooded with cheap, unhealthy foods and that lack nearby, affordable fresh produce. Several also noted that food insecurity in nearby rural areas is just as problematic as in urban areas, but is overlooked (FH 2, 4, 6, 8).

All written mission statements also referred to a goal of increasing food access generally - for all residents - but as Table 1 shows, fewer food hubs specified that their food access commitment is intentionally focused on addressing inequities. Still, a higher proportion of Michigan food hubs compared to hubs nationally self-reported in the survey that their mission is "strongly" related to "increasing healthy or fresh food access to economically disadvantaged communities" (64\% MI vs. 44\% nationally) and to "addressing racial disparities through access to healthy food" (36\% vs. $20 \%$ ). This commitment to equitable food access, however, was still lower than the proportion of food hubs both in Michigan and nationally that saw a strong link between their mission and "improving human health in your community or region" $(91 \%$ MI vs. $57 \%$ nationally) and "increasing access to markets for small and medium-sized farmers" (91\% vs. $82 \%$ ). Addressing food access in lowincome communities was also noted in written mission statements less often than what was selfreported in the survey (36\% written vs. $64 \%$ survey), and no written mission statement mentioned work on food access from a racial-disparities perspective.

Overall, newer food hubs, the nonprofits (and sometimes the mixed legal model hubs), and those most dependent on external revenue were the most likely to indicate a commitment to equitable food access in both the survey and their written mission statements (Table 2). Similarly, while most food hubs noted that they carry out between two and 10 equity-oriented food access activities ${ }^{5}$ (Table 1), those noting the highest number of activities were newer (6.0 activities vs. 3.2 among more

\footnotetext{
4 The following hubs were considered to have a "mixed" legal model: a self-declared "quasi-public," economic development corporation; a subsidiary of a public community college; a project of the local city government and farmers market; a network of producers and businesses that are supported by a partnership between the local co-op, Michigan State University, and the local health department; and a for-profit operation that is highly subsidized currently by the larger, nonprofit operation.

5 O ne for-profit food hub that declined to be interviewed noted in the survey that it is not engaged in food access work.
} 
Table 1. Summary of Food Hub Characteristics, Missions, Food Access Activities, Challenges, and Scaling Up Strategies, by Food Hub, Overall and Nationally

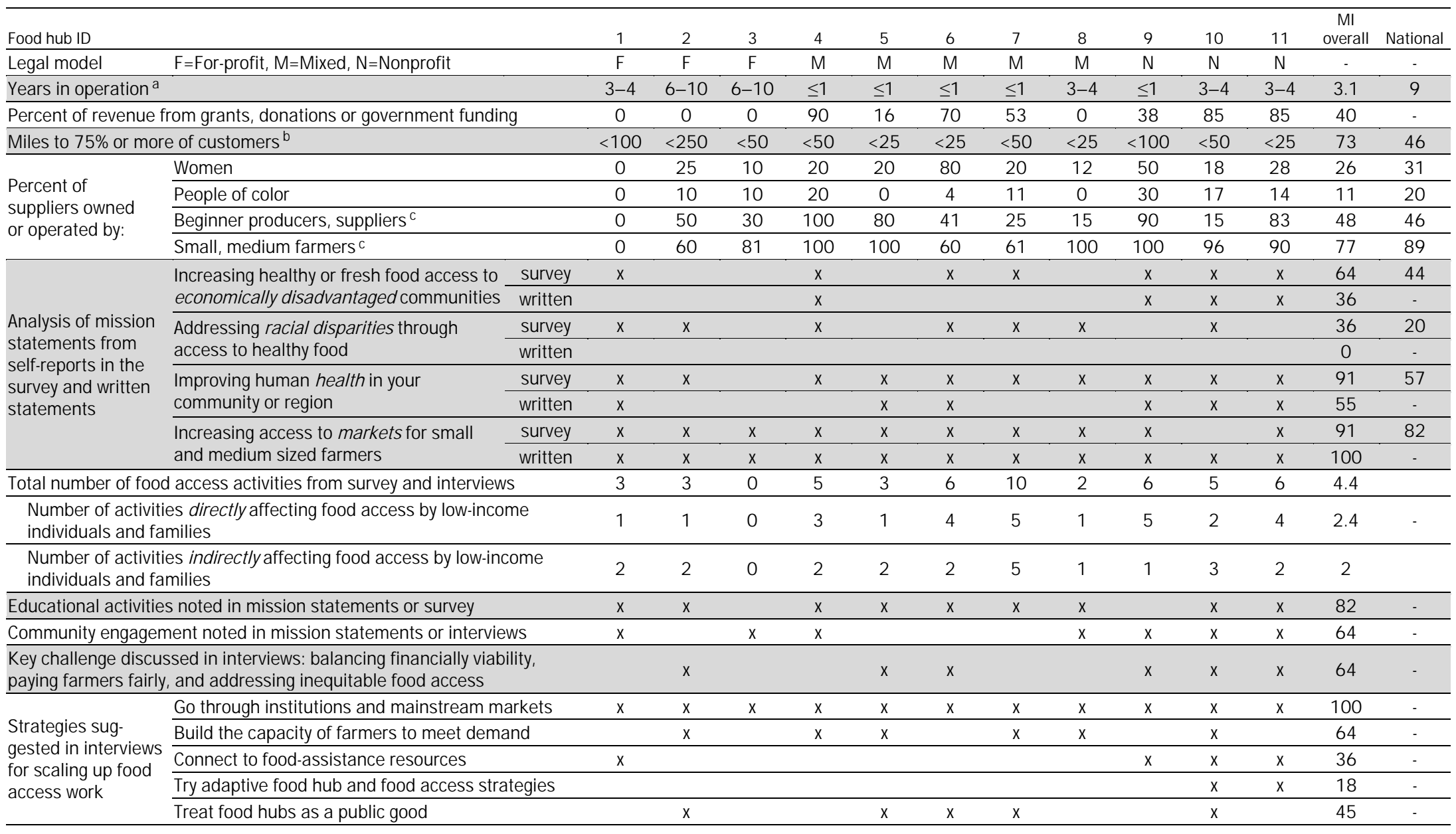

a To maintain food hub anonymity, years in operation is provided as a range, but actual years was used to calculate the average for "Ml overall." National averages for this and other questions are from the 2017 National Food Hub Survey (Colasanti et al., 2018). Answers are blank if the National Survey collected data differently or not at all. See note in Table 2 about the mission statements.

"Food hub managers were asked "Would you say that 75\% or more of your food hub's customers are located. .." and then asked to select the category of miles that applied. Note: 1 mile=1.6 km

c We used the National Survey definition of "Beginner"-starting a business in the last 10 years. Rather than ask if "most" or "all" farm or ranch suppliers were small or midsized, as the National Survey asked, ou survey asked for the percentage of small or midsized suppliers with gross sales less than US $\$ 500,000$. We did not collect the total number of suppliers. 
Table 2. Food Hub Characteristics, Missions, and Views on Challenges and Strategies for Scaling Up Food Access Work Compared Across Groupings of Hubs by Legal Status, Years in Operation, and Percent of Revenue from External Sources

\begin{tabular}{|c|c|c|c|c|c|c|c|c|c|c|c|}
\hline & & & \multicolumn{3}{|c|}{ Average or percent by legal status } & \multicolumn{2}{|c|}{$\begin{array}{l}\text { Average or percent by years } \\
\text { in operation }\end{array}$} & \multicolumn{3}{|c|}{$\begin{array}{l}\text { Average or percent by dependence on } \\
\text { extermal revenue sources }\end{array}$} & \\
\hline & & & For-profits & Mixed & Nonprofits & 3 or more years & $\leq 1$ year & $0 \%$ & $16-53 \%$ & $70-90 \%$ & \\
\hline \multicolumn{3}{|l|}{$\mathrm{N}$} & 3 & 5 & 3 & 6 & 5 & 4 & 3 & 4 & \\
\hline Legal model & \multicolumn{2}{|l|}{$\mathrm{F}=$ For-profit, $\mathrm{M}=$ Mixed, $\mathrm{N}=$ Nonprofit } & - & - & - & $3 \mathrm{~F}, 1 \mathrm{M}, 2 \mathrm{~N}$ & $4 \mathrm{M}, 1 \mathrm{~N}$ & $3 \mathrm{~F}, 1 \mathrm{M}$ & $2 \mathrm{M}, 1 \mathrm{~N}$ & $2 \mathrm{M}, 2 \mathrm{~N}$ & \\
\hline \multicolumn{3}{|l|}{ Years in operation } & 6.7 & 1.5 & 2.2 & - & - & 6 & 0.8 & 2 & \\
\hline \multicolumn{3}{|l|}{ Percent external revenue } & 0 & 46 & 70 & 28 & 53 & - & - & - & \\
\hline \multicolumn{3}{|c|}{ Miles to $75 \%$ or more of customers } & 30 & 100 & 67 & 50 & 80 & 50 & 67 & 100 & \\
\hline \multirow{3}{*}{$\begin{array}{l}\text { Percent of suppliers } \\
\text { owned or operated by: }\end{array}$} & \multicolumn{2}{|l|}{ Women } & 12 & 30 & 32 & 15 & 38 & 12 & 30 & 36 & \\
\hline & \multicolumn{2}{|l|}{ Beginner producers, suppliers } & 27 & 52 & 63 & 32 & 67 & 24 & 65 & 60 & \\
\hline & \multicolumn{2}{|l|}{ Small, medium farmers } & 47 & 84 & 95 & 71 & 84 & 60 & 87 & 86 & \\
\hline \multirow{7}{*}{$\begin{array}{l}\text { Analysis of mission } \\
\text { statements from } \\
\text { self-reports in the } \\
\text { survey and written } \\
\text { statements a }\end{array}$} & \multirow{2}{*}{$\begin{array}{l}\text { Increasing healthy or fresh food access } \\
\text { to economically disadvantaged } \\
\text { communities }\end{array}$} & survey & 33 & 60 & 100 & 50 & 60 & 25 & 67 & 100 & \\
\hline & & written & 0 & 20 & 100 & 33 & 40 & 0 & 67 & 75 & \\
\hline & \multirow{2}{*}{$\begin{array}{l}\text { Addressing racial disparities through } \\
\text { access to healthy food }\end{array}$} & survey & 0 & 40 & 67 & 17 & 60 & 0 & 67 & 75 & \\
\hline & & written & 0 & 0 & 0 & 0 & 0 & 0 & 0 & 0 & \\
\hline & \multirow{2}{*}{$\begin{array}{l}\text { Improving human health in your } \\
\text { community or region }\end{array}$} & survey & 67 & 100 & 100 & 83 & 100 & 75 & 100 & 100 & \\
\hline & & written & 33 & 100 & 100 & 50 & 60 & 33 & 67 & 75 & 임 \\
\hline & $\begin{array}{l}\text { Increasing access to markets for small } \\
\text { and medium-sized farmers }\end{array}$ & written & 100 & 100 & 100 & 100 & 100 & 100 & 100 & 100 & $\circ$ \\
\hline \multicolumn{3}{|c|}{ Total number of food access activities from survey and interviews } & 2.0 & 5.2 & 5.7 & 3.2 & 6.0 & 2.0 & 6.3 & 5.5 & \\
\hline \multicolumn{3}{|c|}{ Educational activities noted in mission statements or survey } & 67 & 100 & 67 & 83 & 80 & 75 & 67 & 100 & \\
\hline \multicolumn{3}{|c|}{ Community engagement noted in mission statements or interviews } & 67 & 40 & 100 & 83 & 40 & 75 & 33 & 75 & \\
\hline \multicolumn{3}{|c|}{$\begin{array}{l}\text { Key challenge discussed in inteniews: balancing financially viability, paying } \\
\text { farmers fairly, and addressing inequitable food access }\end{array}$} & 33 & 40 & 100 & 50 & 60 & 25 & 67 & 75 & I \\
\hline \multirow{5}{*}{$\begin{array}{l}\text { Strategies suggested in } \\
\text { interviews for scaling up } \\
\text { food access work }\end{array}$} & \multicolumn{2}{|c|}{ Go through institutions and mainstream markets } & 100 & 100 & 100 & 100 & 100 & 100 & 100 & 100 & \\
\hline & \multicolumn{2}{|c|}{ Build the capacity of farmers to meet demand } & 33 & 80 & 33 & 50 & 60 & 50 & 67 & 50 & \\
\hline & \multicolumn{2}{|l|}{ Connect to food assistance resources } & 33 & 0 & 100 & 50 & 20 & 25 & 33 & 50 & 尊 \\
\hline & \multicolumn{2}{|c|}{ Try adaptive food hub and food access strategies } & 0 & 0 & 67 & 33 & 0 & 0 & 0 & 50 & \\
\hline & \multicolumn{2}{|l|}{ Treat food hubs as a public good } & 33 & 60 & 33 & 33 & 60 & 25 & 67 & 50 & $\sum$ \\
\hline \multicolumn{11}{|c|}{$\begin{array}{l}\text { a This question asked food hub managers to indicate if these topics were "strongly related," "somewhat related" or "not related" to their missions. A hub has an "x" if they noted a topic as "strongly related." If } \\
\text { blank, they noted "somewhat related" for all topics, except for "racial disparities via food access," which was noted by food hub } 3 \text { as "not related." }\end{array}$} & 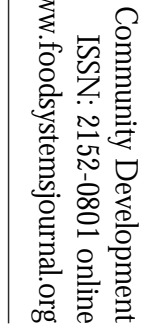 \\
\hline
\end{tabular}


established hubs); moderately dependent on external revenue (6.3 activities), or highly dependent (5.5 activities, compared to those with no external revenue with 2.0 activities); and nonprofits (5.7 activities) or mixed model hubs (5.2 activities, compared to for-profits with 2.0 activities). These activities are described in more detail below, divided by actions that have a direct and indirect impact on low-income food access.

D irect food acoess activities

Food hubs in our study are directly affecting food access in low-income communities by regularly donating to food pantries (6 hubs), accepting federal food assistance (6), and providing transportation to or deliveries from the local farmers market, particularly for seniors (3). Four food hub managers ( $\mathrm{FH} \mathrm{2}, 6,9,10)$ additionally noted in interviews that they sell to institutional markets that serve low-income populations. One hub started selling fresh, local produce to a Meals on Wheels program after seniors started asking for better quality food. This hub also partners with a nonprofit that serves nearly 1,000 free meals a day, five days a week to low-income children in four area schools. Another manager described a partnership where the local high school purchases from the food hub every other week for five months, sending food home with students on the weekends. Two of the food hubs in our study also participate in Michigan's 10 Cents a Meal program, a farm-toschool food purchasing program described further below. O ne of these food hubs is also part of a Farm to Freezer program; run by Goodwill Industries of Northern Michigan, the program flashfreezes locally grown produce while the food hub handles distribution, as the manager explained:

To me, that is a really fine example of how multiple entities are addressing multiple issues that exist within a community in a creative way that is taking a systemic and holistic approach to the challenge rather than [only looking at the] food access problem.... In the north (of Michigan), we can provide nutritious, fresh vegetables for [only] three months out of the year, but we can put infrastructure in place for processing that local produce in a way that can provide fresh frozen product all year around. (FH 2)

Four food hubs, including one with a mixed model and all three nonprofits, also engage in direct-to-consumer sales in low-income communities (FH 7, 9, 10, 11). Managers from three of these hubs have "veggie box" programs that accept federal food assistance or that offer subsidized rates for low-income households. O ne program started as a workplace delivery system to aggregate produce from local farms. To make the program accessible to SNAP (Supplemental Nutrition Assistance Program, or food stamps) recipients, a grant subsidizes boxes half filled by the local food bank and half filled by the food hub. A second hub delivers 50 of its 80 veggie boxes each week to homebound seniors. This latter food hub also started operating a mobile market that accepts SNAP and D ouble Up Food Bucks (explained further below) and goes to businesses, senior centers, Head Start centers, schools, and outdoor sites during the summer. Finally, two of these food hubs also run neighborhood farm stands, which in one case runs for 20 weeks in 21 neighborhoods, most of which are low-income communities of color.

Indirect food access activities

Food hubs also mentioned a number of ways that their work may have an indirect impact on food access. Most food hubs (8 out of 11) partner with other nonprofits that work on food access by offering space, in-kind resources, or other assistance. For example, one hub is part of an umbrella group that runs a weekly food pantry, a farmers market, and several programs to build the capacity for backyard gardening in the city, including one program that employs youth to build garden boxes for low-income, low-mobility, and inexperienced gardeners. Another food hub is supporting a new nonprofit focused on community gardens, helping with logistics, and offering its website for promotion.

Some interviewees also note that food hubs play an educational, placemaking, and communityengagement role that may indirectly affect food access by "increasing the conversation about everything having to do with food" (P 8). Nearly all 
food hub mission statements (FH 1, 4, 5, 8, 10, 11) and eight of the 11 survey respondents (FH 1, 2, 4, $5,6,7,8,10$ ) indicated that their food hubs actively engage in some type of cooking, gardening, job training, or broader food systems education. The majority of mission statements (FH 1, 3, 4, 8, 9, 10, 11) also noted that their food hubs aim to create opportunities for "community participation," demonstrate "concern for the community," "ensure community buy-in and support," "create a food community that empowers," develop a "hub of the community," "increase the ownership of our food system amongst all residents," and "strengthen bonds of civic trust... as well as civic engagement."

Several food hub managers (FH 3, 9, 11), including one for-profit and two nonprofits, described further in the interview how they have attempted to engage local residents. As one forprofit manager described, "We are the canvas upon which the community can draw upon what it wants to do..." (FH 3). This hub is also attempting to become an "informational clearinghouse," to help local food pantries and farmers connect, and to be "neutral territory" when tensions emerge between food security organizations. Another nonprofit food hub manager explained that it recently received a grant to "get back to our community organizing roots, learn about the people and assets in our neighborhood, and help strengthen enterprises that we know exist underground in a neighborhood that isn't supported by the current system" (FH 11). Even by their presence, one food hub partner argued that food hubs are a "physical demonstration of the food system" and can be a mechanism to raise awareness, and even action, around food access and other food systems issues:

It's very hard for people to think abstractly. When you go to Eastern Market or Allen Street or the Flint Market, you say "this is a food hub!" You see people that grow the food, the way it gets aggregated and distributed to people that can't come [to the market] and there's a health clinic upstairs, and a Prescription [for Health Program]. ... At least people can see what you're talking about. I don't know if [food hubs] can solve the problems [of food access], but they allow the public to understand ... [and perhaps, be inspired] to start doing very concrete initiatives. (P 7)

Challenges that L imit Food A coess $\mathrm{E}$ fforts While most food hubs are engaged in food access activities in some manner, interviewees also acknowledged that the impact of these efforts is often small or uncertain. O ne food hub partner observed that "most of the food hubs have a hyper-local impact on food access, within their neighborhood and not much beyond that" (P 2). Another partner who will soon launch a food hub saw the current state of food access work more as a function of the financial uncertainty many new food hubs face, citing how "once it is more figured out where [food hubs] sit economically, that will help to determine their contribution to [food] access" (P 6). This financial precariousness, and the limits it places on how much hubs can do around food access, was often discussed in Food Hub Network meetings as well as our interviews ( $\mathrm{FH} \mathrm{2,}$ $5,6,9,10,11 ; \mathrm{P} 2,3,4,7)$ regardless of the food hub's legal model, years in operation, or dependence on external revenue sources (Table 2). O ne food hub partner likened it to airline safety protocol, explaining that food hubs must remember to "put on your own mask on before helping others" (P 7), ensuring their own financial survival before they try to fix other problems in the food system.

A major reason food hubs struggle financially, some food hub managers (FH 2, 6, 9, 11) believe, is because concentration in the agri-food system is creating a "food crisis" (FH 2). It manifests in obscuring "the real price of food" (FH 9) from the public, creating lopsided competition between local food initiatives and industrially produced food.

In this context, interviewees expressed that food hubs can play a role in addressing food access, but all food hub managers we interviewed and four partners (P 2, 4, 5, 7) think only a "collective and collaborative, community-based approach" (FH 2) can fully address food access, which is "a shared responsibility of the community [that] includes nonprofits, institutions, government, philanthropy, and businesses" (P 4). As one food hub manager added, "It is on all of our shoulders. It is a federal, 
state, local, community-based, and family-based priority" (FH 7). The other four food hub partners (P 1, 3, 6, 8) believe the ultimate responsibility for ensuring equitable food access falls on the shoulders of government, whether through the farm bill, SNAP, public universities, health departments, or urban planning offices. No interviewee, therefore, saw food hubs as the principal answer to the complex problem of food insecurity, because it requires multiple actions and because food hubs can play so many roles, as one food hub partner sees it:

Food hubs are one way that food access could be addressed in communities. It is not the only way and it is not the best way because some of those decisions are going to be made by the community itself. ... There are so many roles that a food hub might play, I don't know that a food hub needs to play all of them.... The problem is too big! I don't think a food hub should hold itself accountable to fix such an enormous problem. ... There are problems that are just too big to solve! (P 8)

In another take on food insecurity, one food hub manager argued that food hubs- at best- are keeping small-scale farmers out of poverty: "When food access is mentioned, farmers aren't necessarily even considered in that equation... The best work we're doing is putting money in the hands of small local farmers and helping to increase their household wealth so that they can eat the stuff that they grow... We are [at least] keeping farmers from being on food stamps" (FH 11). O ne food hub manager also believes that food hubs ultimately would have to ignore "the other part of the equation" - supporting farmland preservation and the viability of farming as a career- if they tried exclusively to ensure that everyone had access to affordable food:

I think that we really have to be careful as a food hub... If our sole focus in the food industry is on the people who are marginalized, then we are not taking a systemic approach to the food crisis that we have in this country... The single biggest challenge is that the amount of revenue generated by [providing equitable food access] is not sustainable as a capitalistic business venture. ... We would be unable to pay the farmers what the food cost. That would be putting a short-term band-aid on a systemic problem. We have traditionally taken the approach in our food system that food should be cheap and we drive down the price to the bottom of the value chain, which makes farming not a viable career choice as a livelihood. If we continue that approach we will not have any farmers. (FH 2)

Scaling U $\mathrm{E}$ fforts to A ddress L ow-Inome

F ood A coess

Despite the challenges, food hub managers and partners we interviewed believe that a number of strategies could enhance the financial viability of food hubs even as they help build markets for local farmers and more equitable food access, outlined below.

W ork through institutions and mainstream mark ets All the food hub managers and food hub partners agreed that the best way to scale up the food access reach of food hubs- while ensuring their own survival and the livelihoods of local farmers- is to work through large-scale institutions or mainstream markets where low-income populations shop and eat the majority of their meals. Three food hubs (FH 6, 7, 9) are exploring partnerships with small grocery and convenience stores, including one idea of incorporating "pop-up farm stands" in grocery stores to gradually increase demand for a more permanent presence. Another mechanism for reaching people where they shop is Michigan's D ouble Up Food Bucks (DUFB) ${ }^{6}$ program, which one manager considers their food hub's "most successful" food access strategy (FH 10). DUFB allows SNAP recipients to double their SNAP benefits for the purchase of fruit and vegetables at participating farmers markets and grocery stores. O ne food hub manager is exploring how to support the independent retailers that are starting to accept DUFB,

${ }^{6}$ See more about D ouble Up Food Bucks: httpp:/ www.doubleupfoodbucks.org/ 
noting how: "I know that getting Michigan produce into the stores and merchandising is one of the biggest challenges. ... We could be the supplier for the D ouble Up stores, we could do the signage, and we could train their staff" (FH 5).

Within the realm of institutional buyers, one food hub manager (FH 2) is starting to see more opportunities to sell to hospitals because of Affordable Care Act incentives to invest in "community benefits" initiatives to cut health care costs (Union of Concerned Scientists [UCS] \& Johns Hopkins Center for a Livable Future [CLF], 2014, p. 7). A food hub partner (P4) also thinks local government could play the same role, by passing citywide food procurement policies for public institutions. Two food hubs in our study are also involved in Michigan's 10 Cents a Meal program. After an initial three-year pilot that launched in 2013 with seven school districts in three counties, the 10 Cents a Meal program ${ }^{7}$ recently secured additional state government match funding to cover 32 school districts in 28 counties. As one manager from a participating food hub explained, sourcing to schools can be logistically complicated without the involvement of a food hub to aggregate local products:

[The idea of incentivizing local food purchases] is great, but how do you get it to the schools? ... Have eight farmers who are all pulling up to the gate of the school throughout the course of the day?! Schools don't have a receiving department and the cost associated with eight different invoices is not feasible. O ur food hub solves a lot of issues by creating one invoice and delivering multiple products. (FH 2)

Build the capacity of farmers to meet demand Despite the potential to serve more institutions, the majority of food hub managers (FH 2, 4, 5, 7, 8, 10) - regardless of their legal model, years in operation, or revenue sources- have needed to build the capacity of local farms to meet the larger volumes and food safety standards institutions demand. As one manager expressed, "We can't scale the farmers we have fast enough to meet the demand we are getting from institutions" (FH 2). Another food hub manager sees its investment in farmer capacity as the best means to ensure its hub's economic viability: "I think one of the biggest leaps for food hubs is that we have a whole new [group] of new farmers who don't know how to sell to food hubs. Farmer development is an investment in our future business" (FH 9). O ne food hub is having to do so much farmer support, it is considering transitioning from a for-profit to a nonprofit model because: "The type of work that we are doing is a lot of supplier hand-holding getting them ready to be distributors ... which means we are not making money. If we are trying to develop strong suppliers it lends itself more to a mission base than a business base." Similarly, another food hub manager noted that farmer capacity-building is the main factor slowing its ability to reach institutional buyers:

We're not going to discard the notion that we can get to institutional buyers... but it is going to be a slow grow. At every point, it will require some capacity building effort for farmers. [Several years ago, local farmers'] presentation of the produce was awful! So we started our business development workshops ... developing a business plan, safe food production, marketing, branding, etc. (FH 4)

Connect more effectively to food assistanœe resources Four food hubs, including one for-profit (FH 1) and all three nonprofits (FH 9, 10,11), believe that one of the most direct routes to increasing the capacity of food hubs to reach low-income consumers would be to improve mechanisms for tapping into federal food assistance. Six of the 11 food hubs surveyed (FH 4, 6, 7, 9, 10, 11), including three of the mixed-model and all three nonprofits, already accept public food assistance, such as SNAP (also known as EBT-Electronic Benefits Transfer). However, several food hub managers (FH 1, 9, 10) said it is not possible to accept federal food assistance benefits virtually, which affects

${ }^{7}$ See more about the 10 Cents a Meal program: https:/ / www.groundworkcenter.org/ projects/ farm-to-school/ 10-cents-a-meal.html 
hubs that sell through online platforms. O ne of these hubs is planning to open a farm store but is daunted by the paperwork that it would take to accept SNAP. The other two food hubs find that the process of accepting SNAP makes their operations inefficient. O ne hub cannot deliver its veggie boxes to SNAP participants as it does other customers, because the EBT card owner must be present to swipe their card, in accordance with federal law. Another hub has organized its box delivery around EBT customer schedules, but deliveries must often be rescheduled when customers are not home, adding additional time and creating a delivery route not based on geographic efficiency.

A larger, related issue for one food hub is its limited capacity to reach more customers on federal food assistance; as one explained, "We're not doing very well reaching EBT customers. ... O ur farm stand is open four days a week, but we have a hard time getting people into that space. We just invested in signage. It has improved food access in the neighborhood but not by a lot. There is a lot of foot soldier organizing stuff that we could do in a better way."

A dapt food hub models and strategies to address food acoess Another idea that emerged in our interviews is to explore more adaptive food hub models and broader strategies to improve food security alongside local food economies. For instance, two of the food hub partners ( $\mathrm{P} 4,7)$ and two nonprofit food hub managers (FH 9, 11) suggested that part of what can reduce their dependence on outside funding is to use the profits from one area to subsidize food access programs that operate at a loss. As one food hub partner has seen, "Food hubs need diverse markets to make it work for access. They need to cross-subsidize. ... They need 70 percent high end so they can do 30 percent low end" (P 4). For one food hub, this meant expanding its customer base to subsidize work with lowincome customers, as staff came to accept that "Y ou can still have your values while selling vegetables to rich people!" Another food hub started selling imported foods like bananas to attract more customers, but this essentially subsidized its local food work and brought prices down for lowincome residents. Its veggie box program, for instance, has an "à la carte" option that offers both local and non-local products, which is currently more popular than the "farmers choice box" entirely from local farms. One food hub partner described the need to consider more flexible food hub models as:

The willingness to say " $\mathrm{OK}$, I'm not going to do what everybody wants, but are there ways to morph so that I can actually do the work of the food hub even better?" That's a huge struggle. ... How do you have a clear mission ... without becoming a purist? Y ou can get to a place where it becomes so sure of itself that it loses its ability to actually adapt and be resilient itself and figure out how to function in that community.... It can become anti more than service oriented. (P 7)

Building from the notion of not becoming a "purist," a second, related question two food hub partners raised (P 2, 3), including one person who previously ran a food hub, is whether the focus on food hubs is too narrow to adequately build local food economies alongside increased food access in low-income communities. As one partner framed it, it may be important to look at a broader supplychain approach:

By looking just at food hubs, we're missing a huge part of these small and midsized distributors. We might not call them food hubs because they sell lemons and coconuts, but they also sell lots of Michigan product, moving and delivering it to small grocers and businesses across the state where we don't see any food hub activity.... In northeast Michigan, one example is a business called Consolidated Fruit Distributors, a 75-year-old family-run produce distributor that drives around to IGAs and comer stores, selling all kinds of produce. They have 10 to 20 SKU's $^{8}$ for local produce that they distribute- they have the infrastructure, and relationships to

${ }^{8} \mathrm{SKU}$ is an industry abbreviation for "Stock Keeping Unit," a unique code assigned to each inventory item. 
deliver products. ... Even though they aren't a food hub, they should be a part of this work. We don't want to stop working with food hubs, but how do we broaden our scope to think about food distribution generally in this state? ... There may be value in widening the scope of food access and food value chain work to integrate more traditional, existing infrastructure and hybrid systems that sell local alongside non-local foods. (P 3)

Treat food hubs as public goods

Finally, tied to the challenges created by the global food system, many interviewees- including managers from diverse types of food hubs (FH 2, 5, 6, 7, 10 ) and nearly all the food hub partners (P 1, 2, 4, $6,7,8)$ - suggested that food hubs could be subsidized or supported through public financing. Especially considering the fact that "our food system is already riddled with subsidies," one food hub manager noted how "I don't know how it's possible to have a business that is paying farmers a fair price and helping low-income families afford food without significant grant funding" (FH 5). For one manager, the preoccupation with making ends meet through sales and grant writing detracts from working on their core social mission. Even with nonprofit status, the manager noted, "I could work more on the projects that mattered more to a nonprofit if I wasn't so worried about our sales [and fundraising]" (FH 10). This manager went on to explain how the only way their nonprofit food hub has been able to support so many diverse programs around food access is because of its subsidies:

Ideally, the sales from the hub will support some of those activities that are less profitable but contribute to food access. That is not yet the case. We are currently $90 \%$ grant-funded and $10 \%$ revenue-funded. We are trying to flip it so that we are $10 \%$ grant-funded and $90 \%$ revenue-funded ... but we aren't close to it being financially viable at all. We would have to do half a million dollars in sales and we aren't close to that.... Without the subsidy that nonprofits have access to, there's no way in hell these initiatives to increase food access would be possible without a nonprofit status. I know there are successful hubs that are for-profit but they are probably not serving a low-income neighborhood.... I think that government and foundations need to be committed to supporting hubs that are located in and serve low to moderate income populations. (FH 10)

Interviewees noted how subsidies, grants, lowinterest loans, and other forms of debt-free capital allow food hubs to experiment, take chances, and tackle complex problems like food insecurity, with "flexibility ... [and the] time and space to make mistakes, to figure things out slowly" (FH 5). D escribing a new mobile market, one food hub manager also described how it "has a lot of potential, but it has taken a lot of flexibility and movement. ... Y ou have to really give something a go to know if it is going to work." In this sense, especially if given the financial backing to do so, food hubs may serve a larger, public purpose, to generate innovative solutions that could eventually be scaled up as one manager put it:

The for-profit model is better for serving the needs of our growers. ... Their aim is to have the triple bottom line. Their primary goal is profit, as it should be. Those hubs that are beholden to grant dollars have state and federal obligations to fulfill the objectives of making sure that all socioeconomic groups have equal access.... I think we have a great responsibility to use state and federal dollars to run programs, take chances, dream big, and to wrap our brain around bigger issues. (FH 7)

Another argument for subsidizing food hubs is that so many are doing what should be the role of the public sector to address food insecurity. D uring a Food Hub Network discussion, for instance, one attendee asked, "How can we improve access to local food in northeast, lower, Michigan? We felt that a food hub is only one way to do that... O ne thing we need to do is more advocacy as it relates to food and food hubs." Several food hub partners (P 1, 2, 6) also pointed out that the farmer capacity-building most food hubs do should be the 
work of publicly funded agriculture extension workers; as one explained, "Food hubs' main role is to drive markets. ... All the technical assistance that we add on tends to blur the focus of a food hub. They typically aren't staffed for all that. That's what [Cooperative] Extension should do" (P 2). Another partner who is launching a food hub similarly argued:

I think there is a broad-level question about how we think about food as a basic service at a municipal level. Food systems planning is starting to happen but it's still not happening that much, so instead we deal with it as a public health crisis.... The nonprofit sector exists in part because of where government stops. [We are] doing in some ways what ... Extension should do. Nonprofits [including food hubs] have stepped up for years to help fill that gap, although I think that ultimately it is a government responsibility. ( $\mathrm{P} 6$ )

Finally, rather than think about support for food hubs as subsidies, one food hub partner argued that the support for food systems interventions, including food hubs, should be seen as an investment: "Cities have resources for economic development. As more people begin to understand that food systems are an economic driver ... we are working on [ensuring that] food systems be identified as an asset for public financing" (P 4).

\section{Discussion}

O ur findings suggest that Michigan's food hubs are still emerging in the current food system landscape, so the role they may eventually play in addressing equitable food access is still uncertain. All food hub managers we spoke to, however, were aware of and concerned about the inequitable food access issues facing communities that surround them, and on average they engage in four different food access activities - at least two that have a direct impact on food access in low-income communities and two with more indirect effects.

Contrary to other arguments that food hubs are best equipped to serve their social missions once they become more established and financially viable (Cleveland et al., 2014; Feldstein \& Barham,
2017; Fischer et al., 2015), our findings suggest the opposite. Food hubs in our study that had been operating for a year or less and were moderately or highly dependent on external funding were carrying out the highest number of food access activities. These hubs were also most likely to state clearly in written mission statements or in our survey that they do not simply focus on food access "for all," but prioritize food access in economically disadvantaged communities. On the other hand, most interviewees also admitted that many of their food access activities are still small-scale and tentative experiments, and all food hubs still find it a challenge to balance their need to become financially viable with their desire to offer affordable food and pay farmers a fair price.

O ur findings are complicated by the fact that the newest and most financially dependent food hubs were nonprofits and sometimes mixed-model hubs, making it difficult to disentangle whether it was their funding base, legal model, or time in operation that influenced their work on food access. At the same time, food hubs in this study that appeared most committed to equitable food access also fit the pattern that Stroink and Nelson (2013) suggest, where food hubs in the early stages of development often "spread themselves too thin," (p. 628) attempting to address all the problems they see in the food system while facing a "poverty trap" (p. 628) that limits their impact. A recent USD A analysis of six food hubs that closed their operations similarly found that, "O ne of the common pitfalls of food hubs is trying to fill all of the gaps in the local and regional food system. This is a rather large and extremely challenging, if not impossible, task, especially for an enterprise that is just starting out. Food hubs often operate within very thin profit margins; taking on too many extraneous projects can quickly drain resources" (Feldstein \& Barham, 2017, p. 60).

Despite the challenges they face, food hub managers and partners we spoke to still see at least five pathways for addressing twin social and economic goals. All discussed, for instance, working more intentionally with institutions that often serve meals to a lange number of low-income populations such as hospitals and schools, an argument scholars have also made (Stahlbrand, 2017). Many 
interviewees also spoke about needing to work even more on building the capacity of farmers to meet the institutional demand for local food, working further with programs that subsidize the cost of fresh, local food, such as D ouble Up Food Bucks, and the need for mechanisms to simplify the process of accepting federal food assistance, especially virtually. Two food hubs are also "crosssubsidizing" their food access work, either by expanding their base of wealthier customers or by incorporating non-local foods, while two food hub partners also suggested a wider scope- to continue working with food hubs but also long-established, local food distribution operations- to further address equitable food access in many places.

Finally, in addition to the number of ways food hubs could attempt on their own to scale up efforts to address food access, others suggested that equity-oriented food hubs should be subsidized. Much like Stroink and Nelson (2013) argue, many interviewees in this study believe that the tradeoff food hubs often face between meeting their social missions and addressing their financial hurdles is not a reflection of the failure of the food hub model, but rather a reflection of the current economic and political system that creates food insecurity alongside economic uncertainty among midscale producers and distributors. Subsidizing access-focused food hubs located in the poorest communities is justified, interviewees argued, based on the variety of public goods food hubs provide, from innovating ways to address access to healthy food, to educating and engaging communities in wider food systems change, and providing what essentially amounts to agriculture extension - all services that other food hub scholars have also documented (Berti \& Mulligan, 2016; Cohen \& D erryck, 2011; Le Blanc, Conner, McRae, \& D arby, 2014; Levkoe \& Wakefield, 2011).

In part, public financing could be one means to help food hubs move out of the poverty trap while maintaining their commitment to equitable food access. Continuing to operate outside the state to fix food systems failures like food insecurity, Levkoe and Wakefield (2011) imply, is akin to justifying further retrenchment of the welfare state. D aftary-Steel, Herrera, and Porter (2015) draw a similar conclusion about urban agriculture, arguing that urban agriculture organizations are expected to be financially self-sustaining while also providing fresh, healthy food to low-income populations, leadership opportunities for marginalized groups, and jobs and income for small-scale producers. They argue that together, these are an "unattainable trifecta... the myth that urban agriculture can and should, alone and without long-term funding investments, simultaneously achieve these three goals" (emphasis added, p. 21).

\section{Conclusion}

Like the assumption that local food is inherently sustainable, healthy, and fair (Born \& Purcell, 2006), similar claims have been made about food hubs: that food hubs can and should increase healthy food access in marginalized communities (Barham, Tropp, Enterline \& Farbman, 2012; Hardy et al., 2016). O ur study suggests that while many food hubs can successfully integrate food access activities into their operations, a food hub's commitment to food access- especially in lowincome communities- is not a given, and even less certain is just how much impact they can have. Food hubs may be one means of increasing affordable, healthy food access in certain scenarios, but it may be unrealistic and unsustainable for many to prioritize local sourcing, farm viability, and equitable food access simultaneously - unless they can figuratively "put on their own mask before helping others," ensuring their own financial stability.

The alternative to long-term public investment in food hubs, urban agriculture, or other local food initiatives is for the public sector to commit to a more comprehensive strategy to address food system failures. Stahlbrand (2017), for instance, argues that rebuilding the "infrastructure of the middle" will not be possible unless "legislation, restructuring of markets, and use of public funds [especially for public-sector food procurement] ... correct imbalances in market power" (p. 83), such as "one size fits all" agribusiness funding (Stroink \& Nelson, 2013, p. 632) and infrastructure, subsidies and policy that cater to industrial agriculture models (Spittler, Ross, \& Block, 2011). These arguments are reinforced by the broader call to rebuild the food systems planning function that many local governments in the U.S. performed at 
the start of the 1900s (Pothukuchi \& Kaufman, 2000; Vitiello \& Brinkley, 2014). As some participants in this study stated, the key is to ensure that governments recognize that public support for food system interventions, such as food hubs, is likely to yield economic, public-health, environmental, and social returns on investment (Roberts, 2014) and is just as critical as their work on housing, roads, schools, and other basic services (Levkoe et al., 2018).

As food hubs mature, there are signs that they are becoming more financially secure and playing a number of important roles in rebuilding the middle of the food system (Barham, 2012; Colasanti et al., 2018), but more robust evidence of their impact on equitable food access is still needed. Considering the nascence of the food hubs in this study, the limited geographic focus, and the small sample size, our findings should not be seen as definitive. Rather, this study should be seen as a point of departure to investigate the geographic, economic, and political scenarios that pose different enabling or limiting factors when food hubs attempt to meaningfully address inequitable food access.

In addition, food hub scholars may need to be clearer about the type of food hubs they are studying. Most research has focused on or assumed that food hubs fit the "instrumental" and "producercentric" definition of the USD A (Horst, Ringstrom, Tyman, Ward, Werner, \& Born, 2011, p. 211), which Berti and Mulligan (2016) refer to as "values-based agri-food supply chain" (p. 7) hubs that tend to be for-profits focused on linking small and midsized farmers to regional buyers. O ur findings tended to show greater commitments to food access among food hubs that fit Horst et al.'s (2011) definition of "community and healthcentric" (p. 211), or what Berti and Mulligan (2016) refer to as "sustainable food community development" (p. 7) models, which tend to be nonprofits and consumer-driven. Food hubs clearly often blend these approaches, but research that is more explicit about a hub's primary focus could help devise more appropriate expectations and conclusions about how to support different food hubs (Horst et al., 2011).

Future research should also examine in more detail the frequency, reach, and duration of food access activities and determine how often and to what extent food hubs are becoming the de facto food systems planners and agriculture extensionists in some communities, as some interviewees in this study implied. Longitudinal case studies would also be useful to investigate how food hub advocates may be attempting to influence local food policy agendas and what happens to their autonomy, innovation, and scale of food-access activities if and when governments begin to invest in food hubs (Levkoe \& Wakefield, 2011).

\section{Acknowledgments}

We would like to thank all of the Michigan food hub managers and partners who offered their insights and experiences, as well as Nicholas McCann and Rich Pirog from the Center for Regional Food Systems, who were involved in early conversations about the structure and focus of this paper.

\section{References}

Abdalla, C. W. (2002). The industrialization of agriculture: Implications for public concern and environmental consequences of intensive livestock operations. Penn State E nvironmental L aw Review, 10(2), 175-192. Retrieved from https:/ / elibrary.law.psu.edu/ pselr/

Atkinson, R., \& Flint, J. (2001). Accessing hidden and hard-to-reach populations: Snowball research strategies. Social Research U pdate, 33(Summer), 1-8. Retrieved from http:/ / citizenresearchnetwork.pbworks.com/f/ accessing\%2Bhard\%2Bto\%2Breach\%2Bpopulations $\% 2 B f o r \% 2 B r e$ search.doc

Barham, J. (2010, D ecember 14). G etting to scale with regional food hubs [Blog post]. Retrieved from the USD A website: https:// www.usda.gov/ media/ blog/ 2010/ 12/ 14/ getting-scale-regional-food-hubs

Barham, J., Tropp, D . Enterline, K., Farbman, J., Fisk, J., \& Kiraly, S. (2012). Regional food hub resource guide. Washington, D .C.: U.S. D epartment of Agriculture, Agricultural Marketing Service. Retrieved from https:/ / www.ams.usda.gov/ publications/ content/ regional-food-hub-resource-guide 
Berti, G., \& Mulligan, C. (2016). Competitiveness of small farms and innovative food supply chains: The role of food hubs in creating sustainable regional and local food systems. Sustainability, 8(7), 616. https:/ / doi.org/ 10.3390/ su8070616

Bom, B., \& Purcell, M. (2006). Avoiding the local trap: Scale and food systems in planning research. Journal of Planning E ducation and Research, 26, 195-207. https:/ / doi.org/ 10.1177/ 0739456X 06291389

Centers for Disease Control and Prevention [CD C]. (2016). M ichigan: State nutrition, physical activity, and obesity profile. Atlanta, G A: Author. Retrieved from https:/ / www.cdc.gov/ nccdphp/ dnpao/ state-localprograms/profiles/michigan.html

Cleveland, D . A., Müller, N. M., Tranovich, A. C., Mazaroli, D. N., \& Hinson, K. (2014). Local food hubs for alternative food systems: A case study from Santa Barbara County, California. Journal of Rural Studies, 35, 26-36. https:// doi.org/ 10.1016/j.jrurstud.2014.03.008

Cohen, N., \& D erryck, D . (2011). Corbin Hill Road Farm Share: A hybrid food value chain in practice. Journal of A griculture, Food Systems, and Community D evelopment, 1(4), 85-100. iscepi https:/ / doi.org/ 10.5304/ jafscd.2011.014.011

Colasanti, K., Cantrell, P., Cocciarelli, S., Collier, A., Edison, T., D oss, J., ... Smalley, S. (2010). M ichigan G ood F ood C harter. East Lansing: Michigan State University Center for Regional Food Systems. Retrieved from https:/ / www.canr.msu.edu/ michiganfood/ uploads/ files/ Charter.pdf

Colasanti, K., Hardy, J., Farbman, J., Pirog, R., Fisk, J., \& Hamm, M. W. (2018). Findings of the 2017 N ational F ood H ub Survey. East Lansing: Michigan State University Center for Regional Food Systems \& The Wallace Center at Winrock International. Retrieved from http:/ / foodsystems.msu.edu/ 2017foodhubsurvey

Cooper, D . (2018). Reframing food hubs: Food hubs, racial equity and self-determination in the South. Atlanta, GA: Center for Social Inclusion. Retrieved from https:/ / www.centerforsocialinclusion.org/ wpcontent/ uploads/ 2018/ 04/ Reframing-Food-Hubs-Report-by-D ara-Cooper-for-Race-Forward-and-Center-forSocial-Inclusion.pdf

D aftary-Steel, S., Herrera, H., \& Porter, C. M. (2015). The unattainable trifecta of urban agriculture. Journal of A griculture, Food Systems, and Community D evelopment, 6(1), 19-32. https:/ / doi.org/ 10.5304/ jafscd.2015.061.014

DeLind, L. B., \& Benitez, J. S. (1990). The reindustrialization of Michigan agriculture: An examination of state agricultural policies. The Rural Sociologist, 10(3), 29-41.

Feenstra, G., \& Hardesty, S. (2016). Values-based supply chains as a strategy for supporting small and mid-scale producers in the United States. A griculture, 6(3), 1-17. https:/ / doi.org/ 10.3390/ agriculture6030039

Feldstein, S., \& Barham, J. (2017). Running a food hub: Learning from food hub closures (Service Report 77, Vol. 4). Washington, D.C.: USD A. Retrieved from https:// www.rd.usda.gov/ files/ publications/ SR77 FoodHubs_Vol4 0.pdf

Fereday, J., \& Muir-Cochrane, E. (2006). D emonstrating rigor using thematic analysis: A hybrid approach of inductive and deductive coding and theme development. International Journal of Q ualitative M ethods, 5(1), 80-92. https:/ / doi.org/ 10.1177/ 160940690600500107

Fischer, M., Pirog, R., \& Hamm, M. W. (2015). Food hubs: D efinitions, expectations, and realities. Journal of $H$ unger and E nvironmental N utrition, 10(1), 92-99. https:/ / doi.org/ 10.1080/ 19320248.2015.1004215

Franklin, A., Newton, J., \& McEntee, J. C. (2011). Moving beyond the alternative: Sustainable communities, rural resilience and the mainstreaming of local food. L ocal E nvironment, 16(8), 771-788. https:/ / doi.org/ 10.1080/ 13549839.2011.574685

Glaza, T. (2013). Building a community-based food system: G reen economic development in central Illinois (Capstone project report). Normal: Illinois State University. Retrieved from https:/ / ir.library.illinoisstate.edu/ cppg/ 4/

Gundersen, C., D ewey, A., Crumbaugh, A., Kato, M., \& Engelhard, E. (2018). M ap the meal gap 2018: A Report on County and Congressional D istrict F ood Inseaurity and C ounty F ood C ost in the U nited States in 2016 . Washington, D .C.: Feeding America. Retrieved from http:/ / map.feedingamerica.org/

Hardesty, S., Feenstra, G., Visher, D ., Lerman, T., Thilmany-McFadden, D ., Bauman, A.,... \& Rainbolt, G. N. (2014). Values-based supply chains: Supporting regional food and farms. E conomic D evelopment Q uarterly, 28(1), 17-27. https:// doi.org/ 10.1177/ 0891242413507103 
Journal of Agriculture, Food Systems, and Community Development

ISSN: 2152-0801 online

https:/ / www.foodsystemsjournal.org

Hardy, J., Hamm, M., Pirog, R., Fisk, J., Farbman, J., \& Fischer, M. (2016). Findings of the $2015 \mathrm{~N}$ ational F ood H ub Survey. East Lansing: Michigan State University Center for Regional Food Systems \& The Wallace Center at Winrock International. Retrieved from http:// foodsystems.msu.edu/ resources/2015-food-hub-survey

Healthy Food Access Portal. (n.d.). Food Hubs. Retrieved from http:/ / healthyfoodaccess.org/ retail-strategies/ foodhubs?destination=node/ 321

Hendrickson, M., Heffernan, W. D., Howard, P. H., \& Heffernan, J. B. (2001). Consolidation in food retailing and dairy. British F ood Journal, 103(10), 715- 728. https:/ / doi.org/ 10.1108/ 00070700110696742

Hodgins, K. J., \& Fraser, E. D. G . (2018). “We are a business, not a social service agency.” Barriers to widening access for low-income shoppers in alternative food market spaces. A griculture and $\mathrm{H}$ uman V alues, 35(1), 149-162. https:// doi.org/ 10.1007/ s10460-017-9811-y

Horst, M., Ringstrom, E., Tyman, S., Ward, M.., Werner, V., \& Born, B. (2011). Toward a more expansive understanding of food hubs. Journal of A griculture, F ood Systems, and Community D evelopment, 2(1), 209-225.

https:/ / doi.org/ 10.5304/ jafscd.2011.021.017

Jablonkski, B. B. R., Schmit, T. M., \& Kay, D . (2016). Assessing the economic impacts of food hubs on regional economies: A framework that includes opportunity cost. A griaultural and Resource E conomics Review, 45(1), 143-172. https:/ / doi.org/ 10.1017/ age.2016.9

Kirschenmann, F., Stevenson, G. W., Buttel, F., Lyson, T. A., \& D uffy, M. (2008). Why worry about the agriculture of the middle? In T. A. Lyson, G. W. Stevenson, \& R. Welsh (Eds.), Food and the mid-level farm: Renewing an agriaulture of the middle (pp. 3-22). Cambridge, MA: MIT Press.

Le Blanc, J. R., Conner, D ., McRae, G., \& D arby, H. (2014). Building resilience in nonprofit food hubs. Journal of A griculture, Food Systems, and Community D evelopment, 4(3), 121-135. http:/ / dx.doi.org/ 10.5304/ jafscd.2014.043.005

Levkoe, C. Z., Hammelman, C., Craven, L., D andy, G ., Farbman, J., Harrison, J., \& Mount, P. (2018). Building sustainable food systems through food hubs: Practitioner and academic perspectives. Journal of A griculture, F ood Systems, and Community D evelopment, 8(2), 107-122. https:/ / doi.org/ 10.5304/ jafscd.2018.082.008

Levkoe, C. Z., \& Wakefield, S. (2011). The Community Food Centre: Creating space for a just, sustainable, and healthy food system. Journal of A griaulture, F ood Systems, and C ommunity D evelopment, 2(1), 249-268. https:/ / doi.org/ 10.5304/ jafscd.2011.021.012

Lovejoy, S. B., Buhler, D ., \& Hanson, S. (2010). Michigan agricultural statistics 2010/ 2011. East Lansing: Michigan D epartment of Agriculture and Rural D evelopment (MD ARD), Michigan State University, and USD A. Retrieved from https:/ / www.nass.usda.gov/Statistics_by_State/ Michigan/Publications/Annual_Statistical_Bulletin/ $\underline{\text { stats11/ agstat11.pdf }}$

MacD onald, J. M., \& Hoppe, R. A. (2018, March 14). Examining consolidation in U.S. agriculture. Washington, D.C.: USD A Economic Research Service. Retrieved from https:// www.ers.usda.gov/ amberwaves/ 2018/ march/ examining-consolidation-in-us-agriculture/

MacD onald, J. M., Hoppe, R. A., \& Newton, D . (2018). Three decades of onsolidation in U .S. agriculture [EIB No. 189]. Washington, D.C.: USD A. Retrieved from https:/ / www.ers.usda.gov/ publications/ pub-details/ ?pubid=88056

Michigan D epartment of Agriculture \& Rural D evelopment [MD ARD ]. (2018). Facts about Michigan agriculture. Retrieved from http:/ / www.michigan.gov/ mdard/ 0,4610,7-125-1572-7775--,00.html

Michigan State University Center for Regional Food Systems [MSU CRFS]. (2017). Michigan Food Hub Learning and Innovation Network [Information sheet]. East Lansing: Author. Retrieved from https:// www.canr.msu.edu/michigan food hub learning and innovation network/

Pothukuchi, K., \& Kaufman, J. (2000). The food system: A stranger to the planning field. Journal of the A merican Planning A ssociation, 66(2), 113-124. https:/ / doi.org/ 10.1080/ 01944360008976093

Qu, S. Q., \& D umay, J. (2011). The qualitative research interview. Q ualitative Research in A coounting and Management, 8(3), 238-264. https:/ / doi.org/ 10.1108/ 11766091111162070

Roberts, W. (2014). Food for aity building: A field guide for planners, actionists \& entrepreneurs. Toronto: Hypenotic.

Rose, N. (2017). Community food hubs: An economic and social justice model for regional Australia? Rural Society, 26(3), 225-237. https:/ / doi.org/ 10.1080/ 10371656.2017.1364482 
Spittler, J., Ross, R., \& Block, W. (2011). The economic impact of agricultural subsidies in the United States. The Journal of Social, Political, and E conomic Studies, 36(3), 301-317. http:/ / www.jspes.org/ index.html

Stahlbrand, L. (2017). Can values-based food chains advance local and sustainable food systems? Evidence from case studies of university procurement in Canada and the UK. International Journal of Sociology of A griculture and F 0od, 24(1), 77-95. http:// www.ijsfa.org/ index.php/ ijsaf

Stevenson, G. W., Clancy, K., King, R., Lev, L., O strom, M., \& Smith, S. (2011). Midscale food value chains: An introduction. Journal of A griculture, F ood Systems and Community D evelopment, 1(4), 27-34. https:/ / doi.org/ 10.5304/ jafscd.2011.014.007

Stroink, M. L., \& Nelson, C. H. (2013). Complexity and food hubs: Five case studies from Northern O ntario. L ocal E nvironment, 18(5), 620-635. https:/ / doi.org/ 10.1080/ 13549839.2013.798635

Surdna Foundation. (2014). Surdna launches $\$ 18 \mathrm{M}$ program related investment fund [Press release]. Retrieved from http:/ / www.surdna.org/

Union of Concerned Scientists [UCS] \& Johns Hopkins Center for a Livable Future [CLF]. (2014). H ospitals and healthy food: $\mathrm{H}$ ow health care institutions can help promote healthy diets [Policy brief]. Retrieved from https:// www.ucsusa.org/ sites/ default/ files/ attach/ 2014/ 08/ hospitals-and-healthy-food.pdf

U.S. D epartment of Agriculture [USD A]. (2010). Slaughter establishment availability- updated maps. Washington, D .C.: Author. Retrieved from https:// www.fsis.usda.gov/ shared/ PDF/ Slaughter_Estab_Maps_080910.pdf

USD A. (2015). Typology. Retrieved from https:// www.agcensus.usda.gov/ Publications/ 2012/ O nline_Resources/ Typology/ typology13.pdf

USD A (2016). New markets, new opportunities: Strengthening local food systems and organic agriculture. Retrieved from https:/ / medium.com/ usda-results/ new-markets-new-opportunities-strengthening-local-food-systems-andorganic-agriculture-17b529c5ea90

Veeck, G., Che, D ., \& Veeck, A. (2006). America's changing farmscape: A study of agricultural tourism in Michigan. The Professional G eographer, 58(3), 235-248. https:/ / doi.org/ 10.1111/ j.1467-9272.2006.00565.x

Vitalist Health Foundation. (n.d.). Food hubs. Retrieved from http:// vitalysthealth.org/ healthy-communitytoolkit/ local-agriculture/ food-hubs/

Vitiello, D., \& Brinkley, C. (2014). The hidden history of food system planning. Journal of Planning H istory, 13(2), 91-112. https:/ / doi.org/ 10.1177/ 1538513213507541

Woods, M. (2014). Family farming in the global countryside. A nthropological N otebooks, 20(3), 31-48. Retrieved from http:/ / cadair.aber.ac.uk/dspace/ bitstream/ handle/2160/30255/Anthropological_Notebooks XX_3 Woods.pdf

Zepeda, L., \& D eal, D . (2009). Organic and local food consumer behavior: Alphabet theory. International Journal of Consumer Studies, 33(6), 697-705. https:/ / doi.org/ 10.1111/ j.1470-6431.2009.00814.x 